\title{
ПОЕТИКА ПУБЛІЦИСТИКИ І ПРОЗИ ВАСИЛЯ СИМОНЕНКА
}

\author{
Ігор Павлюк \\ Інститут літератури імені Т. Г. Шевченка НАН Украӥни \\ вул. Михайла Грушевського, 4, 01001, Київ-1, Україна \\ e-mail:Pihor@ukr.net \\ https://orcid.org/0000-0001-8698-3498
}

У статті проаналізовано поетику публіцистичних та прозових текстів одного зі знакових літераторів «шістдесятників» - журналіста за фахом Василя Симоненка у контексті тогочасної української публіцистики та прози. Акцентовано на формальних, змістових та формозмістових елементах творення поетизованих публіцистичних та прозових текстів на основі авторських та суспільних філософських, психологічних, ідеологічних світоглядних моделей, життєтексту, перспективах їх ангажування у сучасний культурно-інформаційний вітчизняний простір.

Ключові слова: публіцистика, проза, поетичність, ідеологія, журналістика, віршована публіцистика, шістдесятництво.

«А чого ж тоді наші поети не пишуть вірші про колгоспну осінь? Ну хоча б про наше село Глибочок? А то один вдарився в любов. Другий - читаєш, і дивуєшся: десь учора щось подібне читав. Та це ж передова газети! Тільки то проза, а це вірш. Ідейний вірш, нічого не скажеш, а в душі теплоти нема» [15], - це частина діалогу двох героїв симоненківського нарису. Один із них бухгалтер. Йому й належать ці слова.

Дійсно, на жаль, декларативної (не плутати із публіцистичною, віршованою публіцистикою) поезії, подібної до порожньо-пафосних газетних статей завжди було і є багато в українському культурно-інформаційному просторі. Хоча трапляються $\mathrm{i}$ по-справжньому поетичні передовиці, новели, нариси, які з впевненістю можна назвати поезією в прозі, а публіцистику - поетичною. Це повною мірою стосується і прозово-публіцистичного творчого доробку Василя Андрійовича Симоненка.

Щодо критеріїв цієї поетичності. «Поезія: мистецтво слова у власному смислі (тобто вже відокремлено від фольклору) виникає спочатку як поезія у віршованій формі» [2, 463] - читаємо в енциклопедії. Причина виникнення поетичної форми розкрита Гегелем: «Свідком зародження поезії є двовірш, переданий нам Геродотом 3 оголошенням про смерть в бою греків біля Фермопіл. Інтерес був у тому, щоби створити напис, щоби висловитись про відоме діяння перед сучасниками і потомками тільки заради самих слів, так вираз стає поетичним, тобто він хоче стати дією» $[3,170]$.

(C) Павлюк I., 2019 
Поезія, як і мистецтво загалом, не розв’язує реально практичних проблем людства чи окремої нації. Але вона разом із сучасною їй релігією, наукою концентрує у красивій формі основні гуманістичні ідеали, устремління окремої людини, уявлення про саму людину, космос. Поезія - вища форма мови, іії ритмізоване самовираження, адже в ідеалі кожен вірш прагне стати піснею, навіть народною піснею...

Постараємось на прикладах розглянути, як це вдавалося В. А. Симоненкові, який, як говорить одна 3 дослідниць його творчості, «зіграв в українській літературі роль незвичайну, - хоча ні «пророком», ні «предтечею», тобто одинокою з'явою на літературному обрії, не був» $[9,75]$. Ось слова із його щоденника: «Немає нічого страшнішого за необмежену владу в руках обмеженої людини. Голова колгоспу Єременкового села кричав на зборах від безсилля і люті: «Я вам зроблю новий 33-й рік!». Якби в наших вождів було більше глузду, ніж $\epsilon$, подібні крикуни милувалися б небом крізь грати (16.Х.62)» $[18,72]$. Уже із оцих щоденникових записів зрозуміло, що хвилювало поета прозаїка, поета - Симоненка, який був внутрішній етичний лейтмотив його публіцистичної творчості у різних формах: бити «зализаних і приручених», захищати, оспівувати таких, як дід Опанас Кроква (оповідання «Весілля Опанаса Крокви») [12, 298-300], дівчина Ольга та юнак Андрій (новела «Вино 3 троянд») [12, 286-290], хлопці-нафтовики (з репортажу «Хлопці люблять тільники») [16], інтелігенти фізичної праці» - один з колективів шахтарів (нарис «Розправляють крила орлята») [10] та подібних позитивних, багатий душею і розумом людей, вихідців із народу.

До речі, варто сказати, що Василь Симоненко був принциповий та безкомпромісний у виборі об’єктів своєї критики. Ними ставали не лише явні бюрократи, спекулянти, зрадники батьківщини, але й «братці» по перу: письменники, журналісти. Варто згадати лише реакцію Василя Симоненка на «Автобіографію» Євгена Свтушенка, опубліковану ним у французькому журналі «Експрес»: «Хтозна чого більше тут - політичної безвідповідальності чи обивательської манірності. Мене особисто найдужче вразила фраза, яку Євтушенко наводив у своїй промові на своє ж таки виправдання: «І якщо можна дякувати війні, я дякую їй за те, що вона відкрила для мене значення великого слова Батьківщина і дала можливість збагнути, що я - росіянин». Дякувати війні - це або параліч душі або манірність, що межує з ідіотизмом»[19].

Нині складно судити про об’єктивність поетової оцінки тексту іншого, російського, поета без контексту. Зрозуміло лише одне - для Василя Симоненка немає авторитетів, якщо справа торкається сокровенного. Якщо думка навіть визнаного авторитета не збігається із його думкою, він не мовчатиме. В цьому, погодьтесь, теж своя поезія дії, якщо розуміти її глибше: як бунт, як виклик, а не лише як заримовані рядки.

Отже, частково ми вже сказали про симоненківську публіцистику. Відчули, як його слово хоче «стати ідеєю», а отже, й поезією, якщо вірити Гегелю $[3,170]$.

Розглянемо ще кілька моментів з публіцистичних текстів письменника. Звернемо увагу на необхідний атрибут художності - образ, не розбиваючи слова на склади і не визначаючи поетичний розмір (ямб). Ритм прози, якщо він $\epsilon$, не підлягає механічній обробці, як загалом гармонія в гуманітарній сфері не вимірюється алгеброю.

а) «Дні йдуть і йдуть один за одним, як брикет стрічного конвеєра» [10]. Поетичне порівняння. 
б) «Є люди - справжні інтелігенти фізичної праці» [10]. Оксюморон.

в) «...назад тільки раки лазять» [10]. Використання фольклорних елементів.

Навіть саме зізнання автора: «Хай друзі-брикети пробачать, що слова його звичайні, зате ж вони щирі, бо йдуть від усього серця» [10], - свідчить, що нарис поетичний.

Або:

г) «Кріль так і дивиться, щоб таке з’їсти, аби ноги простягнути» [15]. (Метафора, гумористичність).

д) «взявся за гуж, не говори, що не дуж» [15]. Використання фольклорних елементів.

е) «наша доба страшна для плаксунів; для борців вона прекрасна» [11]. Поетичне протиставлення.

є) «Рикошетом доводилось чути» [14]. Метафора.

Це кілька поетичних, поетизованих краплин із джерела симоненківської публіцистики, публіцистичності, поетичності текстів інших жанрів, його високопрофесійна майстерність будувати діалоги, передаючи, скажімо, спонтанність людського мовлення, трансляцію емоцій, у чому теж $є$ поезія, адже $є$ талановита простота $і$ жвавість, безпосередність вислову вираження дії, вміння почути і передати оригінальність людської думки - шекспірівські «заповіді» творення художнього тексту.

Ось іще приклад:

«- До речі, що таке демагог?

Ми перезираємося між собою.

- Довелося мені якось в кабінеті керуючого трестом бути. Дивлюсь, в кутку телевізор стоїть. У нас в гуртожитку приймача немає, а тут, у службовому приміменні телевізор. Натякнув я керуючому: «Може б, подарували б хлопиям?. А він на мене зиркнув, почервонів і каже: «Хлопеиь ти молодий. А демагог. Дивись у мене...» [16].

Тут і ритму практично нема, і метафор - не густо. А поезія - $\epsilon$. Секрет у самій природі таланту. А розгадувати цього секрету - не наше завдання, та й загалом це, здається, тайна вищого, не людського, рівня.

У наступному діалозі - простота (не спрощеність) і не вимушеність:

- На якому морі служив, браток? - питається хлопия.

3 недоречністю, що так не в'яжеться з його могутньою постаттю, він відповідає:

- Служив я на сухопутті, за тисячу кілометрів звідси. Гадав: доберуся до Кременчуцького моря - відведу душу. А тут... Хлопеиьь невесело махнув рукою» [16].

Незважаючи на вміння будувати діалоги, Симоненко вважає, що «характер людини інколи більше розкривають речі, які оточують ¥ї̈, ніж короткі зустрічі, розмови за кухлем пива...» [10].

Розділяючи цю думку, розділяємо й думку й про те, що енергетично містко писати можна лише про сильне, справжнє, адже «в калюжі глибоко не пірнеш, будь ти хоч японським шукачем перлів» (9. XI. 62) [7, 151].

Підсумовуючи сказане про поетичність публіцистики Василя Симоненка, варто сказати, що вона виражена у роздумах, діалогах, монологах дійових осіб, у їх виступах, думках вголос, піснях, народній мудрості, звернена як до побратимів, товаришів, так і до ворогів різних рівнів. 
Навряд чи можна й потрібно зафіксувати чи передбачити всі формозмісти вияву поетичності, до яких вдається винахідливий розум і гаряче серце поета, талант письменника-громадянина? У творчості Василя Симоненка $\epsilon$ певна доля декларативності, ідейно-публіцистичного пафосу, загалом притаманних письменникам-шістдесятникам, але нема штукарства, формалізму, про що він сам, зокрема, зазначив: «Реальною залишилася, як і була, загроза формалістичного недоумства в літературі. Бо хіба не формалізм, коли сотні писарчуків за наперед заготовленими схемами обсмоктують десяток-другий так званих вічних ідей: люби працю, поважай тата і маму, не дивись косо на сусідів. Формалізм починається там, де кінчається думка». Ми, ж, аналізуючи творчість поета, зокрема її публіцистичний контекст, можемо констатувати: Василь Андрійович Симоненко - поет в публіцистиці та публіцист у поезії, короткій (оповідання, новели) прозі, розмежовуючи, звичайно, природу поетичності у прозових художніх творах і в розглянутих вище «злободенних» жанрах.

Варто ще й поговорити про найскладніший корпус творчості поета: його творчість для дітей... «Чимало книжок для малого читача до сих пір заповнюють традиційні кізки, берізки, цапки та вовки сіроманці. Оці штамповані представники тваринного і рослинного світу починають набивати оскому нашій дітворі, - пише Василь Латанський. Казки Василя Симоненка не залежувались на прилавках - малеча має добрий смак. знову ж напрошується висновок: чи не має Симоненко-казкар якогось творчого секрету у підході до маленьких людей. Знову ж магічно проста відповідь: боротьбу одвічних абстрактних понять - добра і зла - автор розвиває просто і дохідливо. Ось як, наприклад, добрий дядько Лоскотон перемагає цареве сімейство:

\author{
Він як прийде, залоскоче, \\ То сміється, хто й не хоче. \\ Тільки де він появлявся, \\ Зразу плач там припинявся $[17,4]$.
}

Так, це вірш. Але згадали ми її у підрозділі, де річ йтиме про казку не випадково. Адже казка виникла насамперед, як розповідний твір «про вигаданих осіб і події переважно з участю фантастичних сил» $[4,110]$. I це вже заслуга самого письменника, що для втілення свого задуму він вибрав саме поетичну форму, зокрема невелику поему.

Отже, симоненківський добрий дядько Лоскотон перемагає цареве сімейство: перемагає темні сльози, тобто архетипне Добро перемагає таке ж архетипне Зло. «Такі казки цікаві для будь-якого віку, якими можуть однаково захопитися як читачі-батьки, так і читачі-діти, адже їх поетичність пов'язана із народнопісенними, фольклорними джерелами. Одне слово, «казки веселі. Цікаві, без позерства і нудьги» [8], - пише про них Василь Латанський.

Щодо поезії новел, оповідань, маленької повісті «Огуда» надрукованої у сорок восьмому та сорок дев'ятому номерах журналу «Україна» за 1988 рік під рубрикою «Чиста криниця», то без сухого аналізу «танцюватимем» від творчого кредо самого їх автора, про яке ми вже говорили:

Ми ж рятуємо всесвіт од сорому,

Од брехні, боягузтва й ганьби. 
Його розшифрування і в новелі «Дума про діда»: «Що ж, пробачте йому (дідові - І.П.), графе Толстой і Антоне Чехов, не ображайтесь на нього могутній Франко і ніжна Лесю, не гнівайтеся, Олександре Блок, Володимире Маяковський і Олександр Довженко. I ще й ще інші. А ті, хто бачив, як сам відривав від рота, оддавав останню зернину фронтові... ті, що бачили ще і мовчали або цвірінькали римами про кохання, нехай самі підуть до його могили і попросять у нього пробачення...».

Це - органічна поезія у прозі із публіцистичною аурою за ритмом, добрим пафосом соціального ангажування. Таємниця таланту, яка схована в таємниці любові, а звідси вже - авторський хист однією фразою передати складні почуття і душевні поривання героя, передати цілісну картину дійсності у їі динамічному розвитку, пошуку природної рівноваги. симоненківського героя - Діда Опанаса Крокву та бабу Орисю повісили фашисти. «Здивованими очима дивилися вони на врятованих ними людей і показували вслід карателям свої сині прикушені язики. Опанас Кроква зроду не мав дітей, а баба Орися, що поєдналася з ним вірьовкою, ніколи не була його дружиною. Кажуть, у юності вони дуже кохалися і хотіли побратись, але батьки не дозволили...» $[12,299]$. «Це оповідання не про фашистських катів... це легенда про велику любов, яка вже на смертельному одрі зачала життя» $[1,140]$. Тобто це - справжня поезія, - якщо розуміти поезію ширше, глибше, ніж формально: «словесну художню творчість; вірші, ритмічну мову» $[4,213] \ldots$

Вище наведено два поетичних уривки з прози Василя Симоненка. I хоча загалом поезія не піддається літературознавчому аналітичному інструментарію (іноді скрупульозний аналіз убиває невидимий, тонкоприсутній поетичний флер), все ж спробуємо делікатно продемонструвати кілька елементів образності з художньої прози письменника за прикладом виявлення образних матриць із публіцистичного матеріалу Василя Симоненка.

a) «Кленучи себе за м'яку вдачу, я все-таки розгорнув жовтий рукопис і мляво занурився в читання» $[13,8]$. Метафоричність.

б) «Тільки тоді, коли тиша стала схожа на мінування динаміту, я люто спитав...» $[13,21]$. Поетичне порівняння, епітет.

в) «а йому ж хотілося випити хоч краплю кохання» $[12,289]$. Метафора.

г) «хто раннього ранку знайде незаплакану квітку, той буде щасливим...» [12, 288-289] Фраза - Поезія.

д) «У сні в неї з очей росли фіолетові квіти» $[12,318]$. Метафора.

е) «Засумувала під перехресним вогнем дівочих зіниць» [12, 321]. Метафора.

Уже з оцих уривків загалом поетичного текстового полотна, $є$ у Василя Симоненка образи свіжі-оригінальні: б), г), д), е), але $є$ й банальні: а), в).

Правда, варто сказати, що банальними деякі мовні конструкції здаються тому, що вирвані з контексту - сиротливі, як окремі ноти з музики талановито композитора...

Якщо звернути увагу на те, звідки взяті найсильніші образи, тропи письменника, то неважко переконатися, що насамперед із його новел. Це закономірно, бо новела як «невеликий розповідний художній прозовий твір про незвичайну життєву подію» $[4,213]$ уже сама собою передбачає поетичну емоційність, наснаженість.

У всіх своїх тринадцятьох невеликих новелах і в «маленькій повісті» Василь Симоненко зостається поетом, значного громадського звучання, у контексті якого й 
мова про його динамічну, «динамітну» («в грудях моӥх намучених / Вибухає аж сто мегатон») публіцистичність.

У текстах письменника без видимого збитку не можна закреслити жодної букви, не можна переставити з місця на місце чи замінити іншим жодного слова. Хоча варто сказати, на його мову були у свій час досі серйозні напади. Варто згадати лише виступ Михайла Кутинського в «Літературній Україні» за 14 грудня 1962 року, який писав: «Зміст (...) висловлювань набагато досконаліший за форму, думки цінніші, вишуканіші за мову» [5]. Не будемо полемізувати з автором із приводу окремих моментів; можливо, він і має рацію як стиліст. А щодо поетичності і технічної вправності, то час вже довів: у творах В.А.Симоненка є риси, властиві кращим зразкам української класичної новелістики і взагалі прози, котра представлена такими іменами як Михайло Коцюбинський, Василь Стефаник, Архип Тесленко, Андрій Головко, Юрій Яновський...

Він, говорячи словами Івана Франка, дійсно мав природний дар і в прозі «думати образами замість абстрактних понять, бачити і малювати пластичні і барвні картини, в кожнім слові дошукуватись на дні живої душі, крові і нервів людських...» $[5,130]$.

Узагальнюючи свої спостереження над фактологічним матеріалом про художньо-публіцистичну та публіцистично-художню творчість Василя Симоненка $\mathrm{i}$ осмислюючи їх особливості, перш за все варто відзначити наявність таких рис, як громадянська мужність, уміння думати і говорити про головне, не обминаючи насущних проблем часу, всього того, чим жили його сучасники і людство загалом.

1. Василь Симоненко сповідував гуманістичну формулу: «найскладніша людина проста»: колгоспний конюх Федір Кравчук, баба Онися, одинока матір, безіменний дід, уманські дівчата...

2. Творчість Василя Симоненка має громадське звучання, тому можна стверджувати, що вона має елементи публіцистичності у широкому значенні цього слова-терміну.

3. Симоненківську публіцистику (у вузькому значенні терміну) можна умовно назвати політичною лірикою, якщо враховувати грецьку семантику кожного із цих слів, де політика - суспільні справи, а лірика - підвищена щиросердна емоційність.

4. Новели, оповідання та маленька повість Василя Симоненка письменника теж мають елементи публіцистичності. Проте для сьогоднішнього читача цій прозі ніби бракує психо-філософського аналітизму, який становить основу сучасної світової художньої прози. Все це свідчить лише і про те, що як прозаїк молодий Василь Симоненко лише починався.

5. У «витязя молодої української поезії рідкісно врівноважені етичні координати, які «діагностував» Олесь Гончар і в передмові до «Лебедів материнства» назвав поета «чистим,. непідкупним - сумлінням своїх ровесників».

6. Як кожен митець, він у чомусь (форма, зміст, формозміст) - новатор, бо запропонував своєю творчістю щось неповторне, властиве лише йому.

7. Тематика творчості Василя Симоненка - саме життя.

8. Василь Симоненко писав просто й дохідливо, «по-народному». У цьому насамперед його схожість із творчістю Шевченка... I простота ця була органічною складовою його таланту.

9. «Лебеді материнства» в поета тісно пов’язані з «лебедями України». 


\section{REFERENCES}

1. Білан М. Відкриваючи духовні острови // Жовтень. 1966. № 4.

2. Большая советская энциклопедия. М. Советская энциклопедия, 1975. Т. 20.

3. Гегель. Сочинения. М., 1958. Т. 14.

4. Гринчишин Д. Г. Короткий тлумачний словник української мови. К.: Радянський школа, 1988. $320 \mathrm{c.}$

5. Здоровега В. У майстерні публіциста: Проблеми теорії психології публіцистичної майстерності / Володимир Здоровега. Львів : Вид. центр ЛНУ ім. Івана Франка, 1969. $169 \mathrm{c}$.

6. Кутинський М. Лист молодим // Літературна Україна. 1962. 14 груд.

7. Лапинський В. Коштовні дарунки // Жовтень. 1965. № 8.

8. Латанський В. Світланка копилить губку // Літературна Україна. 1964. 29 груд.

9. Никанорова О. Поезії одвічна висота. К.: Радянський письменник, 1986. 246 с.

10. Симоненко В. Розправляють крила орлята // Черкаська правда. 1959. 10 квіт.

11. Симоненко В. Короткі інтерв’ю // Літературна Україна. 1962. 16 жовт.

12. Симоненко В. Лебеді материнства. К.: Молодь, 1981. 344 с.

13. Симоненко В. Огуда // Україна. 1988. № 48.

14. Симоненко В. Праця - найкращий вихователь // Черкаська правда. 1958. 28 лист.

15. Симоненко В. Тальківські зустрічі // Черкаська правда. 1962. 24 лют.

16. Симоненко В. Хлопці люблять тільники // Робітнича газета. 1963. 26 трав.

17. Симоненко В. Цар Плаксій та Лоскотон. К.: Веселка, 1988. 16 с.

18. Симоненко В. А. Окрайці думок // Дніпро. 1986. № 6.

19. Симоненко В. Народ - найвищий суддя // Черкаська правда. 1963. 11 квіт. 


\title{
POETICS OF THE JOURNALISM AND PROSE OF VASYL SYMONENKO
}

\author{
Ihor Pavlyuk \\ T. Shevchenko Institute of Literature of the National Academy of Sciences of Ukraine \\ Str. Mikhail Hrushevsky, 4, 01001, Kyiv-1, Ukraine \\ e-mail:Pihor@ukr.net \\ https://orcid.org/0000-0001-8698-3498
}

The article analyzes the poetics of journalistic and prose texts of one of the iconic writers of the «Sixtiers» - a journalist in the specialty of Vasyl Symonenko in the context of contemporary Ukrainian journalism and prose. The article focuses on formal, content and formative elements of creation of poetized journalistic and prose texts on the basis of author's and public philosophical, psychological, ideological ideological models, life ethic, prospects of their engagement in contemporary cultural and informational domestic space. As a direct mirror of life, «newspaper literature», that is, journalism, is in the permanent formation, development, form, content, form content. Adequate social life awaits the writer of artistic discoveries and at the same time the truth of life as an organic essence of true art. And talented journalism is perhaps the simplest form of justification for these ethical and aesthetic expectations. Therefore, we will try to analyze how artistic methods of comprehension of historical time and methods of written influence on social-political events «full of dynamism» have changed, since scientific research objectivism involves conscious ignoring of psycho-philosophical, ideological dogmas and all kinds of prejudices. The formulated questions generate, provoke a whole body of discussion, polemical, scientific and journalistic thoughts, ideas, comments and facts. So, without claiming their final coverage, a monopoly of truth, but for the greatest objectivity, authority in the selection of scientific theoretical literature, we adhere to the principle: to balance the number of opinions of the researchers of the poet's creativity on the specialty of publicists and poetry researchers, some of whom were friends with themselves the poet or just knew him personally. We will try to find between two, sometimes quite opposing views on his life-creation and creativity of this Vasyl Symonenko. The formulated questions generate, provoke a whole body of discussion, polemical, scientific and journalistic thoughts, ideas, comments and facts. So, without claiming their final coverage, a monopoly of truth, but for the greatest objectivity, authority in the selection of scientific theoretical literature, we adhere to the principle: to balance the number of opinions of the researchers of the poet's creativity on the specialty of publicists and poetry researchers, some of whom were friends with themselves the poet or just knew him personally. We will try to find between two, sometimes quite opposing views on his life-creation and creativity of this Vasyl Symonenko.

Key words: journalism, prose, poetry, ideology, journalism, verse journalism, «sixtiers». 